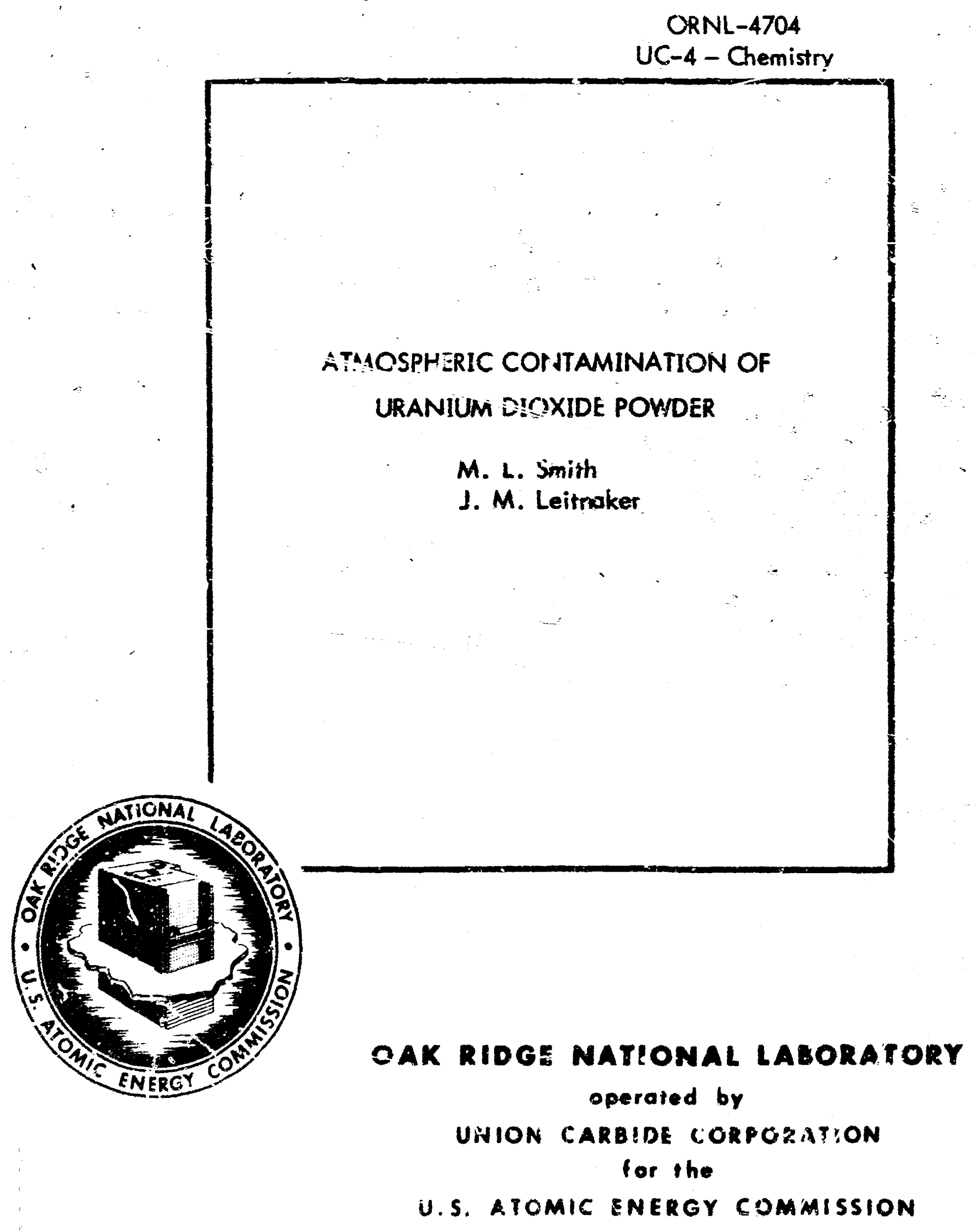




\section{BLANK PAGE}




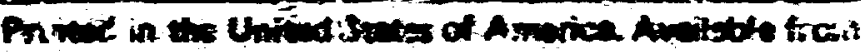

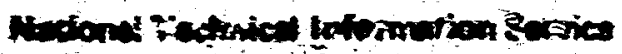

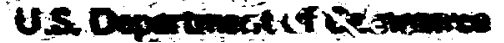

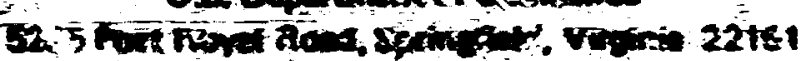

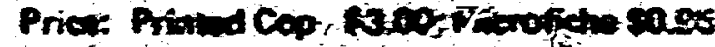

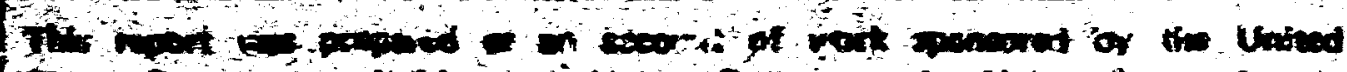

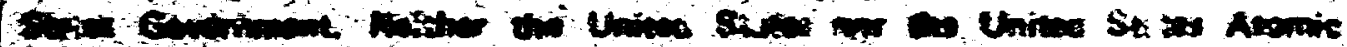

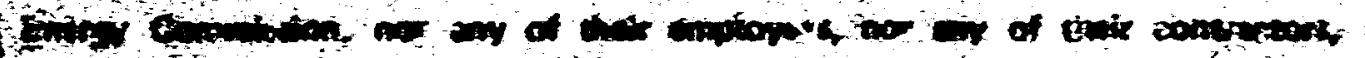

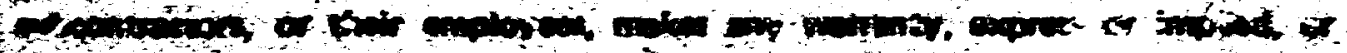

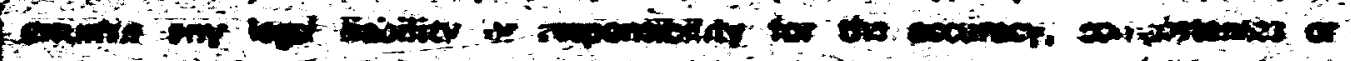

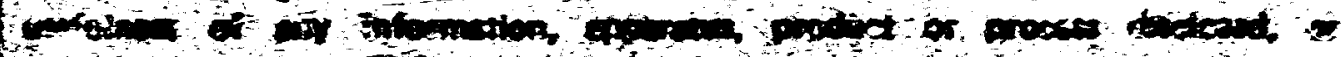

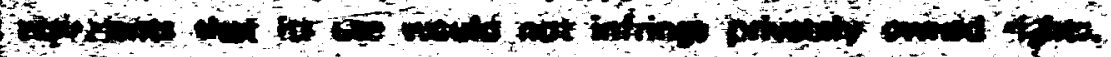


Contract No. H-7405-eng-26

METAIS AND CERAMLCS DIVISIOT

ATMOSPHERIC CONTAMTIATTON OF URAITIUM DIOXIDE PONDER

M. L. Smith and J. M. Leitnaker

JUNE :971

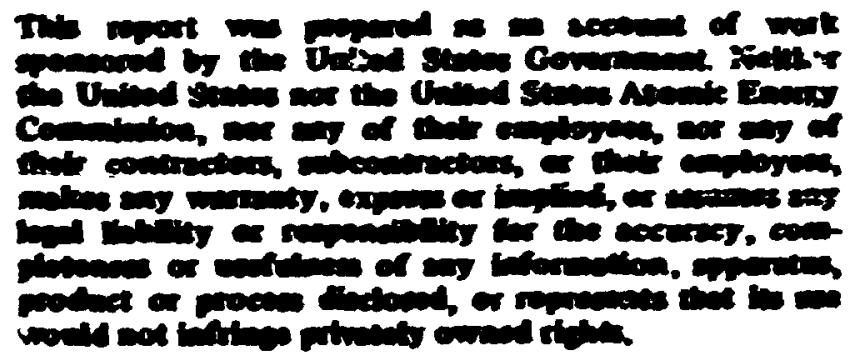

OAY RIDGE MATIOAAL IABORATORY

Oak RIdge, Tennessee

operated by

INION CARBIDE CORPORATION

for the

U.S. ATOMIC ERERGY consission 


\section{CONIEIIS}

Page

Abstract ........................ 1

Introduction ........................ 1

Bxperimental Procechures .................. 2

Results ........................ 4

Discussion ..................... . 11 
AMYOSPHERIC COMTAMCTMITON OF URANTUY DIOXIDS POIDER

M. I. $\operatorname{sunith}^{1} \sin$ J. M. Leitnaker

ABSTRACT

Rocm-temperature contamination of $\mathrm{UO}_{2}$ porder during storage in air of varying wisture contents for several hundred hours was studied. An initial rapid chenisorbtion of uxgen was followed by a slow and independent sorption of water and oxggen. Both the slar sorption retes are nonlinear in the logerithm of time.

The effect of several oxidation and reduction creles on the surface area of the $\mathrm{UO}_{2}$ powder was also studied. Heating the $\mathrm{UO}_{2}$ at $800^{\circ} \mathrm{C}$ decreased the surface area of the porder. Oxidation of the $\mathrm{UO}_{2}$ to $\mathrm{U}_{3} \mathrm{O}_{8}$ at $400^{\circ} \mathrm{C}$ and reduction back to $\mathrm{UO}_{2}$ at 500 to $700^{\circ} \mathrm{C}$ increased the surface area.

\section{IITRODUCTIOI}

Wuch experimental work has been done on room-temperature contamination of $\mathrm{UO}_{2}$ by the atmospinere. A review ${ }^{2}$ in 1961 described the work to that time. Pertinent to our studies, Stevensor and Boyd ${ }^{3}$ found the extent of oxidation of $\mathrm{UO}_{2}$ porder in storage to be a function of the surface area of the material and the time of exposure. Martin ${ }^{4}$ stated that the rate of oxidation of $\mathrm{UO}_{2}$ was not affected by moisture. Pertinert to our studies, the general conclusions of papers by Roberts ${ }^{5}$ and

\section{University.}

'Co-op student from Virginia Polytechnis Institute and State

2J. Belle, ed. , Uranium Dioxdde: Properties and Huclear Applications, U.S. Atonic Energy Comission, 1961.

${ }^{3} \mathrm{~J}$. Stevenson and J. Boyd, The Oxddation of $\mathrm{UO}_{2}$ in Air and Under Conditions of Storege, MYO-5224 (Apri1 1, 1948).

${ }^{4} \mathrm{G}$. L. Martin, The Deterioration of $\mathrm{UO}_{2}$ in Storage, NrO-5228 (May 1, 1948).

${ }^{5}$ L. E.J. Roberts, "The Oxides of Uranium, Fart V. The Chemisorption of Oxgren on $\mathrm{UO}_{2}$ and on $\mathrm{UO}_{2}-\mathrm{ThO}_{2}$ Solid Solutions," J. Chem. Soc. 1954, $3332-3339$. 
Anderson, Roberts, and Harper ${ }^{6}$ are: (1) an initial, rapid chemisorption of oxygen takes place in which at least half the $U^{4+}$ sites on the surface react with oxygen molecules, and ( 2 ) oxidation at room temerature takes place at a rate that is linear in the logarithm of tiwe.

During experiments as the production of sinterable grade $\mathrm{HO}_{2}$, we studied the oxidation of $\mathrm{UO}_{2}$ in air at different partial pressures of water at amient temperature $\left(23\right.$ to $\left.31^{\circ} \mathrm{C}\right)$. In agreement with the literature, we noted that atwospheric conditions during storage measurably offected the moisture content and oxygen-to-metal ratio of the $\mathrm{UO}_{2}$. Our results on the room-temperature oxidation deviated significantly from the linearity with the logarithm of time reported in the literature. We elso investigated the adsorbtion of moisture or the $\mathrm{UO}_{2}$ and the effect of several different heating times and temperatures and recxidation at $400^{\circ} \mathrm{C}$ on the Bronauer-Bunet-Teller (BET) surface area.

\section{EXPERTIMITAL PROCEDURES}

All the samples carre from the same batcin of material. To prepare

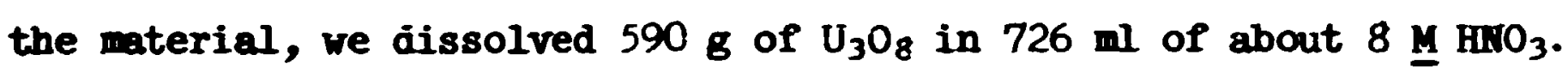
The solution was then placed in a glass coium and jiluted by the addition of about 4 liters of distilled water. The $\mathrm{pH}$ of the solution was increased to 8 by the addition of anhydrous ammonia while the solution was circulated by a pump. The resulting precipitate was then removed from the colum, certrifuged, and air iried in a microwave oven. The precipitate was close to $3 \mathrm{UO}_{3} \cdot 2 \mathrm{KH}_{3} \cdot 6 \mathrm{E}_{2} \mathrm{O}$ by analysis. It was then calcined overnight in air at 600 to $700^{\circ} \mathrm{C}$ in a tube furnace. A friable uranium oxide powder with en oxygen-to-metal ratio of 2.809 and a BET surface area of $4.98 \mathrm{~m}^{2} / \mathrm{g}$ revulted.

Samples were reduced in a slamshell furnace in a quartz glass ivbe. This tube could be removed from the furnace for unloading in an argon atmosphere and evacuated, or gas could ke made to flow through it. The gases used were tank gases; only the hydrogen was purified - it was

${ }^{6} \mathrm{~J}$. S. Anderson, L.E.J. Roberts, and E. A. Harper, "The Oxides of Uranium, Part VII. The Oxidation of U:anium Dioxide," J. Them. Soc. 1955, 3946-3959. 
passed through molecular sieves to remore wisture. Saples were reduced in either hydrogen or carbcn moxide; one saple was reduced by hybrogen and then by carbon monoxide. Reduction tices were generally absut $<$ hr with a $0.5-\mathrm{hr}$ heatup time and $0.25-\mathrm{kr}$ cooldorn tine, although two saples were reduced for langer times in hyärogen to measure the effect on surface area of continued heating in tydrogen. The reduction temperature was generally $700^{\circ} \mathrm{C}$, and variations from this are specifically indicated.

Se ples were stored in air coniaining 12 pga $\mathrm{H}_{2} \mathrm{O}$, abient rater vapor, or saturated water yapor. The saples vere unloaded intc glassstoppered weighing bottles inside an argon-filled glove box. These weighing bottles were rewoved from the glore box, and the initial weight of the saple was obtained by correcting for the weight in air o? the argon-filled bottle. In the prelininary work the saples were stored in ambient air since the importance of vater vapor partial pressure had not been realized. Later sone of the saples vere stored in a ivry box. A fan bloring the air in the dry box through nolecular sieves reduced wisture content to 12 ppa as neasured by a Panametrics hygrometer. Weight changes of $3 a$ ples in try air vere followed with an accuracy of $\pm C .1$ without resoval from the dry box. Other sanples were stored in water-saturated air by placing the sample in a weighing bottle in a screw-top jar, along with a swall, open bottle containing water. Saples stored in saturated air were veighed on sn analytical balance by opening the large jar, capping the weighing bottle, and then imediately resoving to the balance.

The sauples were analyzed for weight percent of uranium and water. The uranium was deternined by combustion to $\mathrm{U}_{3} \mathrm{O}_{8}$ in aggen at $850^{\circ} \mathrm{C}$. Precision of this method al consecutive samples is $\pm C .05 \%$. The water vapor was determined by heating the saples to $10 \mathrm{C}, 200,300$, and $1000^{\circ} \mathrm{C}$ in flowing nitrogen and coulonetrically measuring the water vapor coning off in each temperature ranpe. This nethod is precise to $\pm 5 \%$ and was performed for us by the Analytical Chenistry Divisias. The rest of the sample was assumed to be oxygen. The oxygen-to-met,al ratio was cairulated from the mole percentages of uranium and of oxygen not bound in water. 


\section{RESULTS}

Weight gain for several samples after exposure to air is shom in Fig. I for ti nes up to an hour. There was an initial rapid weight gain, which was clearly gas uptake in a sample when it was removed from its protective atmosphere. In a typical sample with $6.0 \mathrm{~m}^{2} / \mathrm{g}$ surface area the rapid pickup of oxygen was about $1 \mathrm{mg} / \mathrm{g}$ as calculated by linear extrapolation of weight gain to zero time. This indicates a fractional oxygen coverage of 0.74 if an area of $14.1 \AA^{2} /$ molecule is assumed for

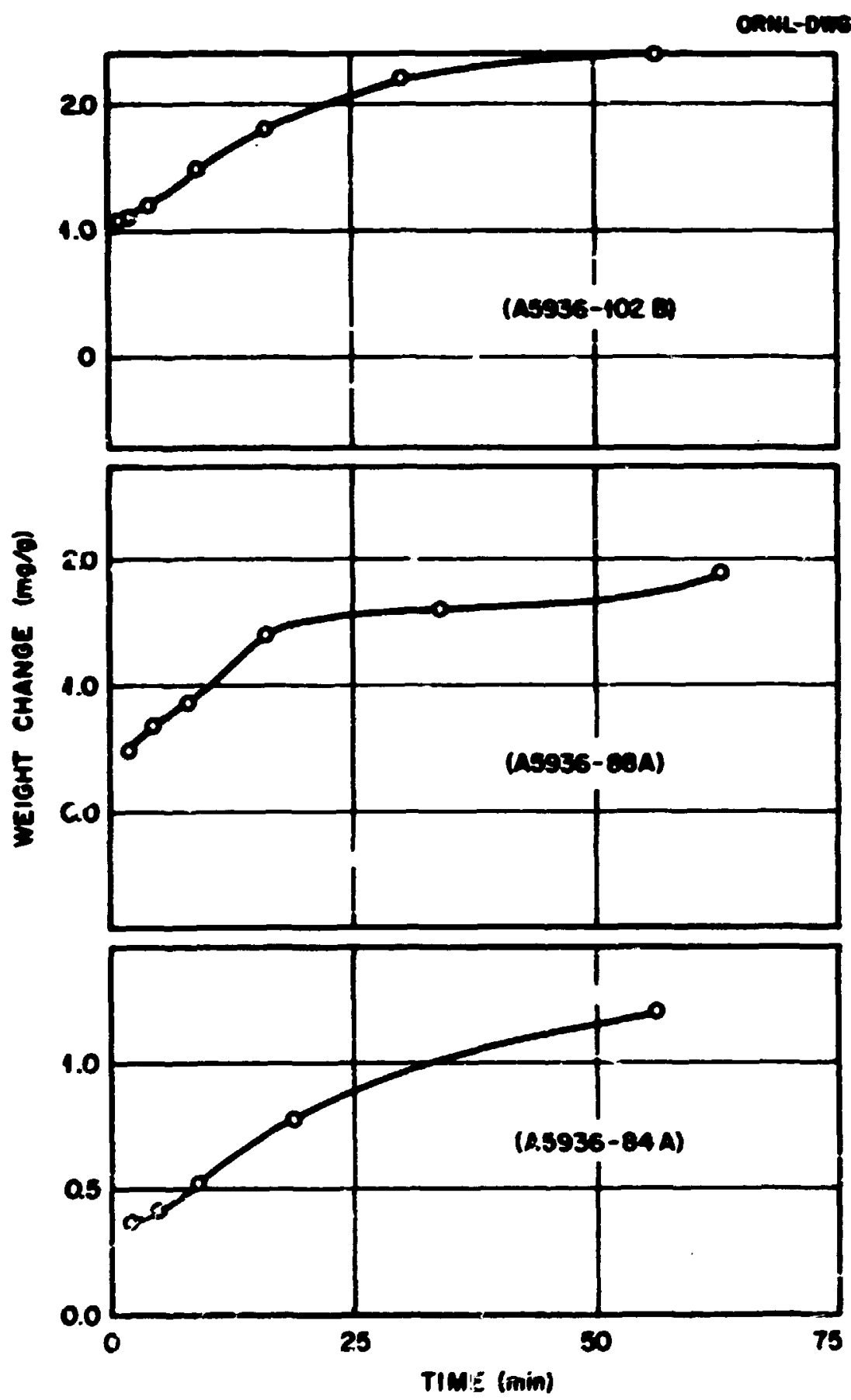

Fig. i. Initial Weight Change of $\mathrm{UO}_{2}$ Samplos After Exposure to Air. (Note that the curve does not extrapolate to zero weight change at zero time.) 
oxvgen. ${ }^{7}$ Others ${ }^{\varepsilon},{ }^{\circ}$ have reported tris initial rapid gas uptake as chemisorption of oxygen with an ave:rage heat of reaction of about $30 \mathrm{kcal} / \mathrm{mole}$ of oxygen. ${ }^{7}$ It seems likely that the heat of this reaction initiates the pyrophoric reaction of finely divided $\mathrm{UO}_{2}$ in air. ${ }^{i 0}$ We observed no pyrophoric reaction, presumably because our samples were smali enough that this heat of reaction could be dissipated.

Weight gain is plotted against logarithm of time in Fig. 2 for a sample of $\mathrm{UO}_{2}$ stored in dry $\left(12 \mathrm{ppm} \mathrm{H}_{2} \mathrm{O}\right.$ ) air for $260 \mathrm{hr}$. Azalys is for moisture before and after storage shored that less than $10 \%$ of the weight

${ }^{7}$ I. F. Ferguson and J.0.M. McConnell, "Heat of Adsorption of Oxygen on Uranium Dioxide at $-183^{\circ} \mathrm{C}$, Proc. Roy. Soc. 241A, 67-69 (1957).

${ }^{8}$ L.E. J. Roberts, "The Oxides of Uranium, Part V. The Themisorption of Oxygen on $\mathrm{UO}_{2}$ and on $\mathrm{UO}_{2}-\mathrm{ThO}_{2}$ Solid Solutions," J. Chem. Soc. 1954, 3332-3339.

${ }^{9}$ J. S. Arderson, L.E.J. Roberts, and E. A. Harper, "The (xxides of Uranium, Part VII. The Oxidation of Uranium Dioxide," J. Chem. Soc. $1955,3946-3959$.

${ }^{10}$ M. J. Bannister, A Survey of the Storage Behavior of Uranium Dioxide, AAEC/TM.396 (1967).

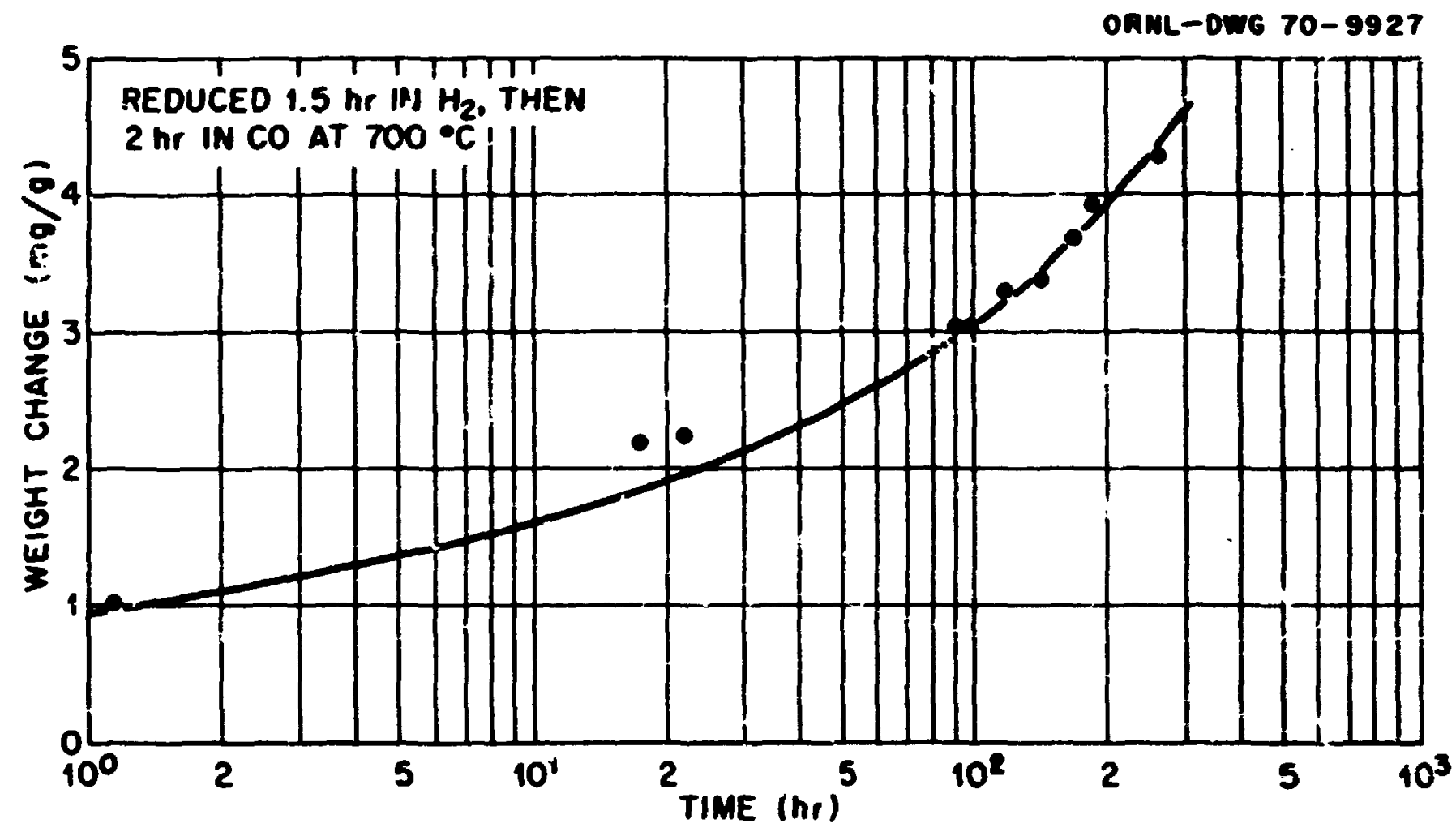

Fig. 2. Weight Gain of Reduced $\mathrm{UO}_{2}$ with Surface Area of $6 \mathrm{~m}^{2} / \mathrm{g}$ Stored in Dry Air (12 ppm $\mathrm{H}_{2}$ O). (Sample A5936-136.) 
gain recorded for the sample was due to moisture adsorption. Thus, in contrast to oxidation studies of a few hours duration reparted in the literature, 8 the weight gain was a slor oxidation and was not linear in the logarithm of time. Similar results were obtained for our other samples. In agreement with the literature; ${ }^{9}$ this slos axidation was rearij linear in the logarithm of time during the first few hours, but departure from linearity became clearly apparent after about $100 \mathrm{hr}$.

Figure 3 is a plot of the weight gain for a simple stored in moisture-saturated air for $260 \mathrm{hr}$. Table 1 compares a sample stored in moisture-saturated air, a sample stored in dry air, and the sample before storage. From the data in the fourth column, one sees both samples oxidized to nearly the same extent regardless of moisture adsurbed. This is in agreement with previous literature. 11

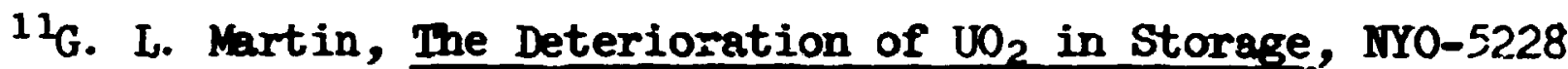
(May 1, 1948).

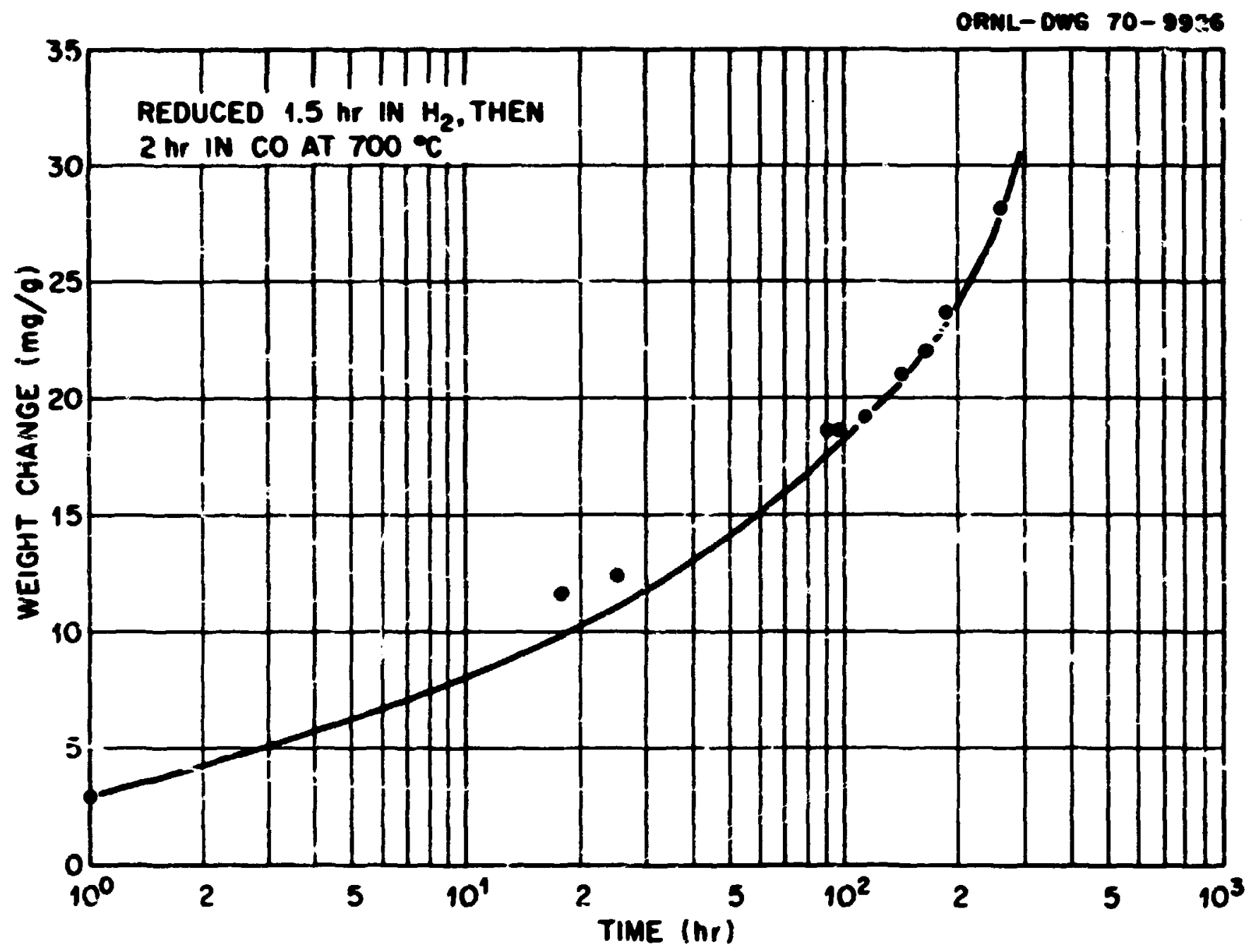

Fig. 3. Weight Gain of CO-Reduced $\mathrm{UO}_{2}$ with a Surface Area of $6 \mathrm{~m}^{2} / \mathrm{g}$ Stored in Water-Saturated Air. (Sample A5936-134.) 
Table 1. Moisture Adsorption and Oxidation of $\mathrm{UO}_{2}$ After Storage in Air

\begin{tabular}{|c|c|c|c|}
\hline Sample & Treatment & $\begin{array}{l}\text { Total Mois ure } \\
\text { in Sample } \\
\text { (ppm) }\end{array}$ & $\begin{array}{l}\text { Oxagen-to- } \\
\text { vetal vole } \\
\text { Ratio }\end{array}$ \\
\hline A5936-116 & $\begin{array}{c}\text { Caicined } \mathrm{U}_{3} \mathrm{O}_{8} \text { retuced } \\
3 \mathrm{hr} \text { at } 700^{\circ} \mathrm{C} \text { in } \mathrm{H}_{2}\end{array}$ & 548 & $2.000 \pm 0.005$ \\
\hline$A 5 \fallingdotseq 36-118$ & $\begin{array}{l}\text { Pars of A5936-116 after } \\
\text { storage for } 36 \text { days in } \\
\mathrm{H}_{2} \mathrm{O} \text {-saturated air }\end{array}$ & 25,600 & $2.112 \pm 0.005$ \\
\hline A5936-I22 & $\begin{array}{l}\text { Part of } A 5936-116 \text { after } \\
\text { storage for } 31 \text { days in } \\
\text { air wi:h } 12 \mathrm{ppm} \mathrm{H}_{2} \mathrm{O}\end{array}$ & 1,326 & $2.120 \pm 0.005$ \\
\hline
\end{tabular}

Noisture determinations of three typical sampies after various treatments are given in rable 2. Much of tha moisture adscrbed on the sample can be removed at $100^{\circ} \mathrm{C}$ in dry nitrogen. For axample, sample A5936-118 had 25,600 ppm moisture after storage 36 days in moisture-saturated air, as compared to $548 \mathrm{ppm}$ for the sample berere storage. Of this, 24,800 ppm was removed between room temperature and $100^{\circ} \mathrm{C}$. The samples continued to gain weight in both dry and watersaturated air after $200 \mathrm{hr}$, as can be seen in Figs. 2 and 3. Thus, the storage time necessary to reach equilibrium of the $\mathrm{UO}_{2}$ with dry or moisture-saturated air cannot be determined in the time interval over which we observed the samples.

Table 2 also shows that the amount of water sorbed during storage at room temperature depends on the partial pressure of water. Figure 4 shows weight changes of three samples as a runction of storage time in ambient air. Storage of $\mathrm{UO}_{2}$ in ambient air is seen to result in erratic changes in weight, which depend on the day on which the samples are weighed. These erratic changes in weight are probably a result of varicitions in the partial pressure of water in the ambient air.

In contrast to the results obtained on co-reduced sampics, shown in Fig. 3, weight changes became erratic after about $100 \mathrm{hr}$ for sampies rediced only in hydrogen ard stored in moisture-saturated air. This effect is illustrated in Fig. 5 and is possibly an effect of hydrogen 
Table 2. Noisture Remeral from $\mathrm{UO}_{2}$ Sarples During Heat ing

\begin{tabular}{|c|c|c|c|c|c|}
\hline \multirow[t]{2}{*}{ Saple } & \multirow[t]{2}{*}{ Treat,ment } & \multicolumn{4}{|c|}{$\begin{array}{c}\text { Woisinure Removed (ppo) Between } \\
\text { Te peraiires, }{ }^{\circ} \mathrm{C}\end{array}$} \\
\hline & & $23-100$ & $100-200$ & $200-300$ & $j: 2-1000$ \\
\hline A5936-116 & $\begin{array}{l}\text { Calcined } \mathrm{U}_{3} \mathrm{O}_{8} \text { reduced } \\
3 \mathrm{hr} \text { at } 700^{\circ} \mathrm{C} \text { in } \mathrm{F}_{2}\end{array}$ & 1 & 148 & 150 & 249 \\
\hline A5936-118 & $\begin{array}{l}\text { Part of } 35930-116 \text { after } \\
\text { storage for } 3-6 \text { days in } \\
\text { H }_{2} 0 \text {-saturated air }\end{array}$ & 24,772 & 324 & 232 & 240 \\
\hline A5936-122 & $\begin{array}{l}\text { Part of } 55930-i 16 \text { efter } \\
\text { storage for } 31 \text { days in } \\
\text { air vith } 12 \text { ppm } \mathrm{E}_{\mathrm{c}} \mathrm{c}\end{array}$ & 615 & 310 & 175 & 226 \\
\hline
\end{tabular}

To sisndaraize the effect of the unloading gl.we box ainosphere, the starting aterial was analyzed at essentially the sane tine that the storage procetures were start:ed.

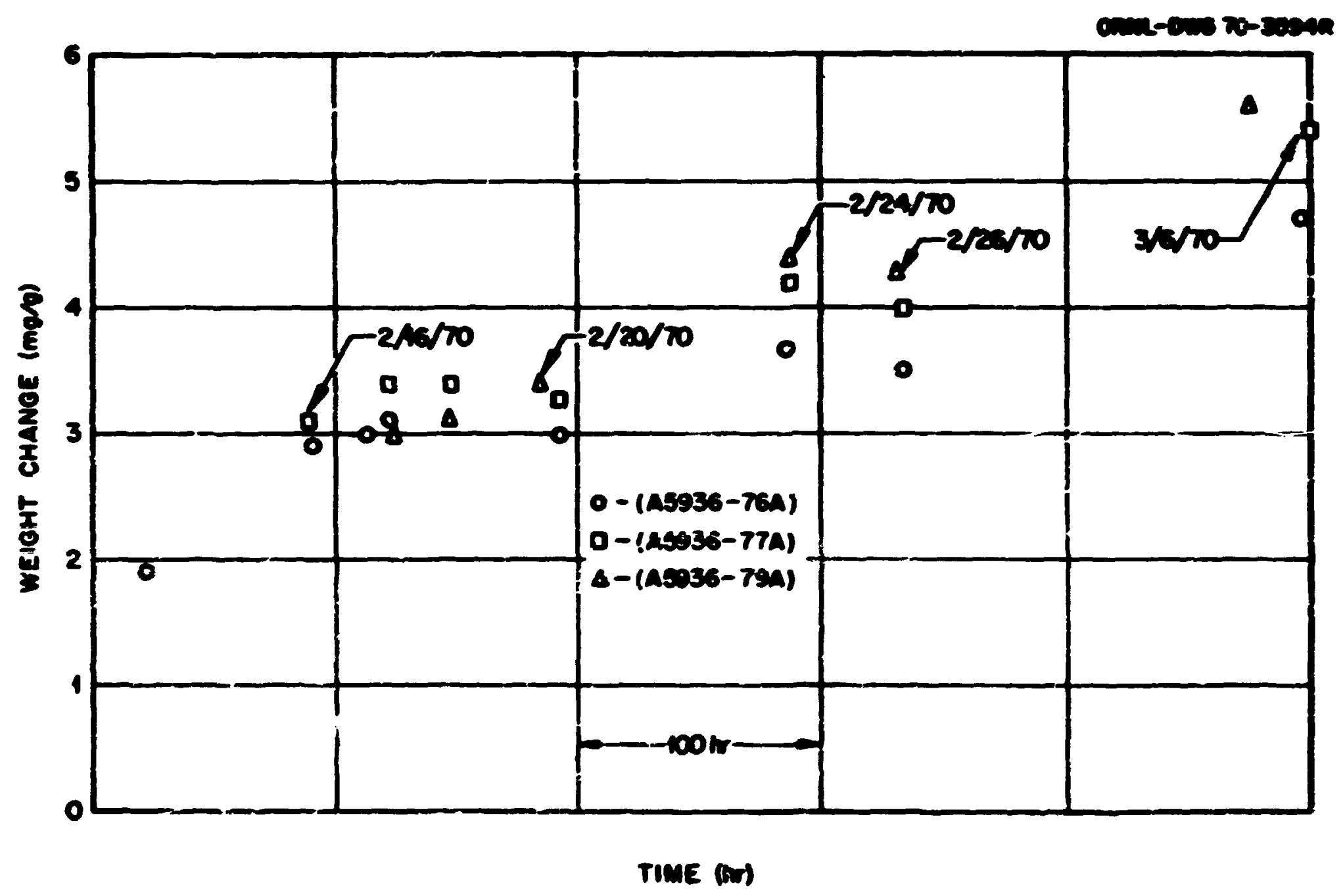

Fig. 4. Total Weight Gain of $\mathrm{UD}_{2}$ Stored Under Ambient conditions. 
OnNL-OWn 70-9e20

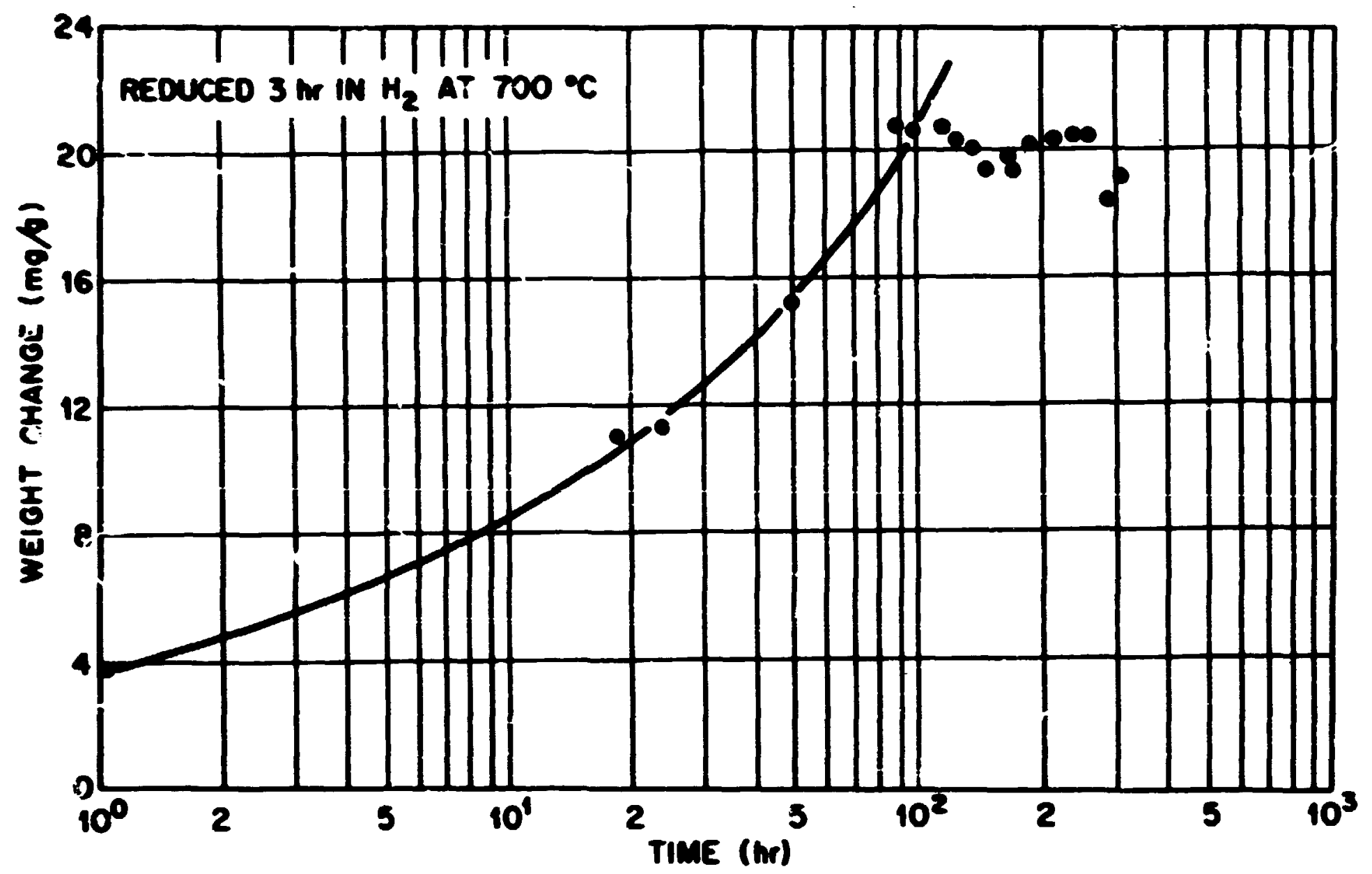

Pig. 5. Weight Gain of Hydrogen-Reduced Sample Stcred in WaterSaturated Air (15936-118).

adsorbed on tre $\mathrm{UO}_{2}$. Roberts ${ }^{12}$ reprited that $\mathrm{CO}$ is not acisorbed by the $\mathrm{WO}_{2}$ during reduction as is hudrogen, so the $\mathrm{UO}_{2}$ reduced in $\mathrm{CO}$ should be lor in adsorbed gases before exposure to air.

A constant 210 to $260 \mathrm{ppan}$ of $\mathrm{H}_{2} \mathrm{O}$ wes renored between 300 and $1500^{\circ} \mathrm{C}$ from all the sapples reduced in hydrogen (see Table 3). This water was clearly different from that picked up by the saples during storage since it was renoved at a higher temperature and was unchanged by storage conditions or surface area.

The results of BET sirface area analysis of our semples are given in Table 4. This shors that reduction or oxidation at lor temperatures increased the BCI surface area. Horever, heating the celcined material in orgren at $800^{\circ} \mathrm{C}$ decreasea the BDT surface area.

12.I.E.J. Boberts, The Adsorption and Absorption of Cases by Uranium Dioxdde, ABRB-C/R-887 (Rar. 5, 2953). 
Table 3. Moisture Renored from $\mathrm{UO}_{2}$ Between 300 and $1000^{\circ} \mathrm{C}$ in Analysia

\begin{tabular}{|c|c|c|c|}
\hline Sayple & Treatment & $\begin{array}{l}\text { Surface Area } \\
\qquad\left(\mathrm{n}^{2} / \mathrm{g}\right)\end{array}$ & $\begin{array}{l}\text { Moisture Removed Between } \\
300 \text { and } 1000^{\circ} \mathrm{C} \\
\text { (pp) }\end{array}$ \\
\hline A5936-116 & $\begin{array}{l}\text { calcined } \mathrm{U}_{3} \mathrm{O}_{8} \text { recuced } \\
3 \mathrm{hr} \text { at } 700^{\circ} \mathrm{C} \text { in } \mathrm{H}_{2}\end{array}$ & 6.00 & 249 \\
\hline A5936-118 & $\begin{array}{l}\text { Pert of } 15936-116 \text { stored } \\
36 \text { days in } \mathrm{H}_{2} 0 \text {-8atcrated } \\
\text { air }\end{array}$ & 6.00 & 240 \\
\hline A5936-122 & $\begin{array}{l}\text { Part of } 15936-116 \text { stored } \\
31 \text { days in air with } \\
12 \text { pge } \mathrm{H}_{2} \mathrm{O}\end{array}$ & 6.00 & 226 \\
\hline A5329-2 & $\begin{array}{l}\text { Calcined } \mathrm{U}_{3} \mathrm{O}_{8} \text { heated } \\
4 \text { days at } 800^{\circ} \mathrm{C} \text { in } \mathrm{O}_{2} \text {, } \\
\text { then reduced } 4 \mathrm{hr} \text { at a } \\
\text { ix terg of } 700^{\circ} \mathrm{C} \text { in } \mathrm{H}_{2}\end{array}$ & 0.532 & 213 \\
\hline A5329-3 & $\begin{array}{l}\text { Calcined } \mathrm{U}_{3} \mathrm{O}_{\mathrm{g}} \text { heated } \\
3 \text { dars at } 8 \mathrm{O}^{\circ} \mathrm{C} \text { in } \mathrm{O}_{2} \text {, } \\
\text { then reduced } 4 \mathrm{\text {in }} \text { at } \\
700^{\circ} \mathrm{C} \text {, then } 16 \mathrm{hr} \text { at } \\
550^{\circ} \mathrm{C} \text { in } \mathrm{B}_{2}\end{array}$ & 1.04 & 257 \\
\hline A5329-6 & $\begin{array}{l}\text { Calcined } \mathrm{I}_{3} \mathrm{O}_{8} \text { reduced } \\
3 \mathrm{hr} \text { in } \mathrm{H}_{2} \text { at } 700^{\circ} \mathrm{C}\end{array}$ & & $\begin{array}{c}229 \\
\left(\text { analysis run in } \mathrm{H}_{2}\right) \\
156 \\
(\text { analysis run in air) }\end{array}$ \\
\hline A5936-137 & $\begin{array}{l}\text { Calcined } \mathrm{U}_{3} \mathrm{O}_{8} \text { reduced at } \\
700^{\circ} \mathrm{C} .1 .5 \mathrm{hr} \text { in } \mathrm{H}_{2} \text {, then } \\
2 \mathrm{hr} \text { in } \mathrm{CO}\end{array}$ & & 83 \\
\hline A5936-147 & $\begin{array}{l}\text { Calcined } \mathrm{U}_{3} \mathrm{O}_{8} \text { heated } \\
3 \text { days at } 800^{\circ} \mathrm{C} \text { in } \mathrm{O}_{2} \text {, } \\
\text { then reduced } 4 \mathrm{hr} \text { at } \\
700^{\circ} \mathrm{C} \text { in } \mathrm{CO}\end{array}$ & 135 & 104.3 \\
\hline
\end{tabular}


Table 4. Surface Areas of $\mathrm{WO}_{2}$ Saples After Several Different Oridation and Reduction Ireatments

\begin{tabular}{|c|c|c|}
\hline Saple & Treatment & $\begin{array}{l}\text { BES } \\
\text { surface Area } \\
\left(\mathbf{m}^{2} / 8\right)\end{array}$ \\
\hline$\$ .5936-63$ & $\begin{array}{l}\mathrm{U}_{3} \mathrm{O}_{8} \text { from wich all semples were taken; } \\
\text { calcined overnight at } 600-700^{\circ} \mathrm{C} \text { in air }\end{array}$ & 4.98 \\
\hline A.5936-138 & $\begin{array}{l}\text { Calcined } \mathrm{U}_{3} \mathrm{O}_{8} \text { reduced in } \mathrm{CO} \text { about } 3 \mathrm{hr} \\
\text { at } 700^{\circ} \mathrm{C} \text { and cooled to } 300^{\circ} \mathrm{C} \text { in } \mathrm{CO} \text {, } \\
\text { then te rocis temperature in } \mathrm{Ar}\end{array}$ & 5.52 \\
\hline A:5936-116 & $\begin{array}{l}\text { Calcined } \mathrm{U}_{3} \mathrm{O}_{8} \text { reduced in } \mathrm{H}_{2} \text { about } 3 \mathrm{hr} \\
\text { at } 700^{\circ} \mathrm{C} \text { and cooled in static } \mathrm{Ar}\end{array}$ & 6.00 \\
\hline $15936-147$ & $\begin{array}{l}\text { Calcined } \mathrm{U}_{3} \mathrm{C}_{8} \text { heated } 3 \text { days in } \mathrm{O}_{2}^{\circ} \text { at } \\
800^{\circ} \mathrm{C} \text {, then reduced in } \mathrm{CO} \text { at } 700^{\circ} \mathrm{C} \\
4 \mathrm{hr} \text { and cooled in } \mathrm{CO}\end{array}$ & 1.35 \\
\hline A5329-1 & $\begin{array}{l}\text { Calcined } \mathrm{U}_{3} \mathrm{O}_{8} \text { heated } 4 \text { days in } \mathrm{O}_{2} \text { at } \\
8 C \mathrm{CO}^{\circ} \mathrm{C}\end{array}$ & 0.338 \\
\hline 1.5329-2 & $\begin{array}{l}\text { Part of sample } 15329-1 \text { heated } 4 \mathrm{hr} \text { at } \\
700^{\circ} \mathrm{C} \text { and cooled in } \mathrm{H}_{2}\end{array}$ & 0.532 \\
\hline 1.5329-3 & $\begin{array}{l}\text { Calcined } \mathrm{U}_{3} \mathrm{O}_{8} \text { heated in } \mathrm{O}_{2} \text { at } 600^{\circ} \mathrm{C} \\
3 \text { days, then reduced in } \mathrm{H}_{2} 3 \mathrm{hr} \text { at } \\
700^{\circ} \mathrm{C} \text { and } 16 \mathrm{hr} \text { at } 550^{\circ} \mathrm{C} \text {, and cooled } \\
\text { in } \mathrm{H}_{2}\end{array}$ & 1.04 \\
\hline A5329-5 & $\begin{array}{l}\text { Part of } A 5329-3 \text { heated in } 0_{2} \text { at } 400^{\circ} \mathrm{C} \\
18 \mathrm{hr}\end{array}$ & 2.06 \\
\hline A5329.7 & Part of A5329-5 reduced at $500^{\circ} \mathrm{C} 24 \mathrm{hr}$ & 3.04 \\
\hline
\end{tabular}

\section{DISCUSSIOa}

Several useful interpretations can be made of the results of our experinents. The pyrophoric reaction of $\mathrm{UO}_{2}$ when first exposed to af.r is raused by the heat of renction of the chenisorption of a monolayer of oxggen. Reoucing the temperature of $\mathrm{UO}_{2}$ belor room terperature and spreading the $\mathrm{NO}_{2}$ out into a thin layer before exposure to air will allow this heat of reastion to be dissipated withost starting a pyrophoric reaction.

Slon long-time oxddation of the $\mathrm{UC}_{2}$ occurs with further storage in alr after the short-time chemisorption of oxvgen. Binsp this slow 
oxidation will affect the sintering properties of the oxide, 13 a bnowledge of its extent is ingortant. Table 5 shours what, increase in oxygen-tonetal ratio was observed for saples stored in dry air, but the maximum oxsen-to-metal ratio that a saple would attain after storage in air cannot be deternined from our experiments, since the saples continued to oxidize for as lang as they rere observed. A lack of knowledge of the linit of $\mathrm{UO}_{2}$ oxidation and of the norphology of the $\mathrm{UO}_{2}$ prevents deternination of the rate-controlling mechanisn of this slow oxidation.

Table 5. Increase in Oxgren-to-yetel Ratio for Several $\mathrm{UO}_{2}$ Samples During Storage in Air with 12 ppm $\mathrm{H}_{2} \mathrm{O}$ at $28^{\circ} \mathrm{C}$

\begin{tabular}{lccc}
\hline Sample & $\begin{array}{c}\text { Storage } \\
\text { Time } \\
\text { (days) }\end{array}$ & $\begin{array}{c}\text { Surface Area } \\
\left(\mathbf{n}^{2} / \mathbf{g}\right)\end{array}$ & $\begin{array}{c}\text { Increase in } \\
\text { Oxygen-to-yetal } \\
\text { Ratio }\end{array}$ \\
\hline A5936-122 & 31 & 6.00 & 0.120 \\
A5936-142 & 33 & 5.52 & 0.115 \\
A5936-135 & 12 & $\sim 5.8^{\mathrm{b}}$ & 0.072 \\
A5936-..20 & 27 & 1.35 & 0.023 \\
\hline
\end{tabular}

$\approx 0.005$.

bistimate based on surface areas of samples treated in about the sane ray.

The $\mathrm{UO}_{2}$ was also found to adsorb molsture during storage. Since almost all of the molsture adsorbed on the samples can be removed at the boiling point of water, the adsorption process is probably physical adsorption of water on the surface of the $\mathrm{UO}_{2}$ rather than chemisorption. Therefore, the adsorption would be expected to have a heat of reaction of less than about $10 \mathrm{kcal} /$ mole. Multilayer adsorption with a lor activation enersy would also be expected. There are not enough data on different water vapor partial pressures, though, to inoicate what adsorpticn lsotherm the water vapor would follor.

${ }^{13}$ K. W. Lay and R. E. Carter, "Role of the $0 / U$ Ratio on the Sintering of $\mathrm{UO}_{2}, "$ J. Nucl. Nater. 30, $74-87$ (1969). 
Besides the woisture that was adsorbed on the $\mathrm{UO}_{2}$ and rewored at $100^{\circ} \mathrm{C}$, there was always some moisture removed at a higher temperature. Analysis of sarples of $\mathrm{WO}_{2}$ reduced in hydrogen revealed that $220 \mathrm{pp}$ of wisture was siways obtained from the sarple between 300 and $1000^{\circ} \mathrm{C}$. Since this moisture was independent of the surface area of the saple, the effect was dependent on some bulk property (see Table 3). He could not determine from our experiments whether this absorbed noisture was bound in the $\mathrm{UO}_{2}$ as moisture or as hydrogen, in equilibriun with the reducing atrosphere. A sample that was analyzed in the presence of oxygen shared somewhat less misture removed between 300 and $1000^{\circ} \mathrm{C}$ than the same sample una'yzed in nitrogen. This way be because oxidation occurring before $300^{\circ} \mathrm{C}$ freed some of the moisture absorbed in the sample. The samples that were reduced in carbon monoxide contained about half as much adsorbed moisture as samples reduced in hydrogen; this moisture probably was in equilibrium with the moisture or hydrogen impurity in the carbon monoxide.

Useful data about analytical techniques also resulted from our studies of $\mathrm{UO}_{2}$. The molsture content of the sample was determined by analyzing for moisture after the sample was exposed to ambient air for only a few seconds. It is necessary to obtain the initial weight of the $\mathrm{UO}_{2}$ after reduction if an accurate initial percent uranium is to be determined. Initial oxidation of the sample occurs quickly, so the sample is storea for about $2 \mathrm{hr}$ in ambient air before transfer to a platinum boat for uranium analysis. The weight of the sample in the boat was corrected for the weight change during storage. The percent oxygen was determined by subtracting the percent uranium and percent moisture from $100 \%$, since the $\mathrm{UO}_{2}$ was $10 \mathrm{w}$ in impurities. The percent uranium in samples that had been stored could best be calculated by correcting the initial percent uranium for the weight gain during storage. For the purposes of analysis all the moisture obtained from the $\mathrm{UO}_{2}$ was assumed to be bound on the $\mathrm{UO}_{2}$ in the form of $\mathrm{H}_{2} \mathrm{O}$.

We showed that the BET surface area of $\mathrm{UO}_{2}$ can be adjusted by oxidation and reduction of the $\mathrm{UO}_{2}$. Both oxidation of $\mathrm{UO}_{2}$ and reduction of $\mathrm{U}_{3} \mathrm{O}_{8}$ can increase the surface area of the sample. Reducing the $\mathrm{U}_{3} \mathrm{O}_{8}$ for 
about 2 hr at $500^{\circ} \mathrm{C}$ rould probably give the greatest increase in surface aren during reduction. Oxdiation of $\mathrm{NO}_{2}$ at $400^{\circ} \mathrm{C}$ increases the surface area, but the surface area of the material can be decreased by continuing to heat the material at $800^{\circ} \mathrm{C}$ in oxgen after the meterial is completely oxidized to $\mathrm{U}_{3} \mathrm{O}_{8}$.

After the initial surface oxidation of the sargle the oxdation rate was close to linear in the logarith of time for bbout $100 \mathrm{hr}$. The oxidation rate after this $100 \mathrm{hr}$ was wore rapid than an extrapolation of the linear graph would have predicted. 